\title{
Applying Real-Time Quantitative PCR to Fusarium Crown Rot of Wheat
}

\author{
A. C. Hogg, R. H. Johnston, and A. T. Dyer, Department of Plant Science and Plant Pathology, Montana State Uni- \\ versity, Bozeman 59717-3150
}

\begin{abstract}
Hogg, A. C., Johnston, R. H., and Dyer, A. T. 2007. Applying real-time quantitative PCR to Fusarium crown rot of wheat. Plant Dis. 91:1021-1028.

Fusarium crown rot (FCR) of wheat is a persistent problem that causes significant losses worldwide. In Montana, FCR is caused primarily by Fusarium culmorum and F. pseudograminearum. Recently, a real-time quantitative PCR (QPCR) assay was developed for FCR using primers and probes specific for a segment of the trichodiene synthase (tri5) gene. The purpose of this study was to determine the utility of QPCR for accessing FCR severity on wheat in field experiments. In 2004 and 2005, plots of spring and durum wheat were inoculated with varying levels of $F$. pseudograminearum oat inoculum and grown under rain-fed conditions. Two weeks prior to harvest, plants were collected from the plots and assessed for FCR severity and analyzed by QPCR for Fusarium DNA quantities. Disease severity scores (DSS) and Fusarium DNA quantities were positively correlated with each other for all three cultivars in 2004 but for only the durum cultivar in $2005(P<0.05)$. In 2004 , grain yields for both spring wheat cultivars were negatively correlated with Fusarium DNA quantities $(P>0.05)$. When DSS and Fusarium DNA quantities negatively correlated with yield, both measurements were comparable in predicting yield reduction $(R=-0.64$ and -0.77 , respectively). Results indicate that this QPCR assay is effective in measuring FCR severity in wheat.
\end{abstract}

Additional keyword: TaqMan

In Montana (Northern Great Plains) and other semiarid regions of the world, Fusarium crown rot (FCR) of wheat (Triticum aestivum L.) is a persistent problem that causes significant losses $(8,9,11,16,17)$. In the Pacific Northwest of United States, winter wheat losses attributed to FCR were estimated at $9 \%$ of total yield in 1994 $(24,29)$. Statewide estimates are not available for Montana but in Hill, Judith Basin, and Roosevelt Counties, FCR-related spring wheat losses were estimated at $8 \%$ in 2002 , or about $\$ 4.45$ million (W. Grey, personal communication).

FCR is caused by a complex of fungi including Fusarium culmorum (W. G. Sm.) Sacc., F. pseudograminearum (O'Donnell $\&$ T. Aoki; group I), and $F$. graminearum Schwabe (group II). In other regions, $F$. avenaceum (Fr.) Sacc., F. acuminatum Ellis \& Everh., F. equesiti (Corda) Sacc., Bipolaris sorokiniana (Sacc.) Shoemaker, and Microdochium nivale (Fr.) Samuels \& I. C. Hallett also have been included in the crown rot disease complex $(2,10,11,15,16$, $25,30,31,37)$. In addition to causing crown rot, the members of the FCR complex also are known to cause Fusarium head blight,

Corresponding author: A. T. Dyer

E-mail: adyer@montana.edu

Accepted for publication 23 March 2007.

doi:10.1094/PDIS-91-8-1021

(C) 2007 The American Phytopathological Society or head scab, which has reached epidemic levels in some of the more humid wheatproducing regions of the United States (38).

Infective propagules of Fusarium spp. overwinter on crop residues as mycelia or, in the case of $F$. culmorum, in the soil as durable chlamydospores. These propagules infect newly sown plants, eventually colonizing their crowns and lower internodes as they develop (10). Symptoms associated with FCR of wheat include stand reductions and the rotting of root, crown, and stem tissues that take on a distinctive chocolate-brown color. In Montana-grown hard red spring wheat, the browning of stem tissues rarely occurs past the second internode, whereas browning up to the fourth internode has been reported for hard red springs grown in the Pacific Northwest $(24,29)$. Under drought conditions, plant defenses weaken and Fusarium spp. invade and obstruct the vascular tissues. Severe infections can result in the abortion of tillers and the production of "white-heads" $(8,9,12,17,23,28)$.

Traditional methods for evaluating FCR severity involve the scoring of mature wheat tillers using a subjective scale that's based on the intensity and distance brown discoloration extends up the tillers. FCR severity scales typically are divided into four or five categories that range from 0 to $100 \%$ browning of an internode. After scoring the tillers, the data can be manipulated several ways for analysis. Some examples are to calculate a disease severity index (equation factoring in incidence and severity; 6), the incidence of stem browning (17), the percentage of tillers in each severity category $(24,29)$, or an average CRR (36). Paulitz et al. (24) and Smiley et al. (29) demonstrated that yield losses correlated best with the percentage of tillers where browning had extended to the fourth internode. White-head incidences and basal browning also have been shown to be good predictors of yield loss (17). Because traditional procedures are labor intensive, time consuming, and vary greatly from evaluator to evaluator, a better system of measuring Fusarium crown rot severity is needed.

With the advent of real-time quantitative polymerase chain reaction (QPCR), researchers possess the unprecedented ability to accurately quantify a specific pathogen within a host plant. QPCR involves the monitoring of PCRs using fluorescent dyes. By comparing the amplification pattern of an unknown sample against that of known standards, the quantity of target DNA in the unknown sample can be estimated (14). The two main chemistries employed by QPCR are SYBR Green I and dual-labeled fluorescent probes, or TaqMan probes. SYBR Green I is an intercalating agent that fluoresces when it is bound to any dsDNA, whereas TaqMan probes fluoresce only when the fluorochromes are released by polymerase activity. Where fluorescent probes are employed, QPCR assays are sensitive, highly specific, and can be performed in a relatively short amount of time (approximately $2 \mathrm{~h}$ ).

Several QPCR assays have been designed to detect the presence of specific Fusarium spp. within various plant and food materials $(7,13,26,27,32,35)$. For studying FCR of small grains, Strausbaugh et al. (32) developed a TaqMan-based QPCR assay to quantify the FCR complex in wheat and barley roots. With primers and probe designed from the trichodiene synthase (tri5) gene of $F$. graminearum, their assay detects not only $F$. graminearum but also F. culmorum and F. pseudograminearum. Applying their assay to greenhouse studies, Strausbaugh et al. (32) found significant correlations between percent infected root area and Fusarium DNA quantities in F. culmorum-inoculated plants. In field studies, they found no correlation between disease severity index and Fusarium DNA quantities in roots for plants sampled at Feekes growth stage (GS) 10.1 to 10.5 (late boot to flowering). 
Although demonstrating that their QPCR assay was a promising technique for diseases evaluation of seedlings in controlled environments, they did not address several concerns about their assay. In particular, the relative sensitivity of the assay among $F$. culmorum, $F$. graminearum, and $F$. pseudograminearum was not examined, nor was the relationship between traditional visual disease categories and Fusarium DNA quantities. In addition, their research focused on evaluating seedling roots for disease severity, whereas most FCR evaluations are done using mature stem tissues as described above.

The purpose of this study is to build on the work of Strausbaugh et al. (32) in evaluating QPCR for FCR disease assessment. To accomplish this we addressed (i) sampling and DNA isolation protocols for mature stem tissues, (ii) the specificity of the QPCR assay reported by Strausbaugh et al. (32) among three FCR pathogens it detects, and (iii) relationships among traditional visual CRRs, grain yields, and Fusarium DNA quantities.

\section{MATERIALS AND METHODS}

Culturing. To obtain large quantities of mycelia for DNA isolations, fungal isolates were grown for 7 days at $22^{\circ} \mathrm{C}$ in $600-\mathrm{ml}$ Roux culture flasks containing $25 \mathrm{ml}$ of clarified liquid V8 media (10\% V8 juice and $\mathrm{CaCO}_{3}$ at $1 \mathrm{~g} /$ liter). The flasks were inoculated with four $1-\mathrm{cm}^{2}$ agar plugs from actively growing cultures. Mycelium was collected under vacuum using a Bückner funnel and Whatman no. 4 filter paper. Collected mycelium was washed with sterile distilled water (SDW) three times and then freeze dried. To obtain macroconidia, Fusarium isolates were grown on carnation-leaf agar media (CLA) [5 to 10 pieces of sterile carnation leaf [about 5 $\left.\mathrm{mm}^{2}\right]$ per $2 \mathrm{ml}$ of $2 \%$ water agar) for 3 weeks, after which sporodochia were harvested with a sterile needle and placed in 1 $\mathrm{ml}$ of SDW. The concentration of macroconidia in suspension was determined using a Levy-Hausser counting chamber (C. A. Hausser \& Son, Philadelphia).

DNA isolations. DNA from mycelia and macroconidia was isolated using the FastDNA kit (QBiogene Inc., Irvine, CA) per the manufacturer's instructions with the following modifications. The extraction buffer consisted of $800 \mu \mathrm{l}$ of CLS-VF buffer and $200 \mu \mathrm{l}$ of 25:24:1 phenol:chloroform:isoamyl-alcohol ( $\mathrm{pH}$ 8.0). Fungal samples were homogenized in the FastPrep FP120 Instrument (QBiogene Inc.) for $30 \mathrm{~s}$ on speed $5.0 \mathrm{~m} / \mathrm{s}$. Before eluting DNA, the binding matrix was vacuum dried in a SpeedVac SVC100 (Savant, Farmingdale, NY) to remove any residual ethanol. Total DNA was eluted in a final volume of $50 \mu \mathrm{l}$ of molecular grade water and spectrophotometerically quantified using a SPECTRAmax Plus 384 (Molecular Devices, Sunnyvale, CA). Fungal DNA samples were diluted 1:5 with moleculargrade water for QPCR analysis.

Due to the tough, dry nature of mature stem tissues, a few modifications were made to the fungal DNA isolation procedure to accommodate mature stem tissues. This included the addition of another ceramic ball to the homogenization tubes, the presoftening of samples by leaving them in CLS-VF extraction buffer on ice for $1 \mathrm{~h}$ prior to homogenization, and the FastPrep FP120 settings being increased to a speed of $6.0 \mathrm{~m} / \mathrm{s}$ and a time of $45 \mathrm{~s}$. To enhance the removal of fibrous stem material, the initial centrifugation step was extended to $12 \mathrm{~min}$, and $25 \mathrm{mg}$ of polyvinylpolypyrrolidone was added to homogenization tubes to remove humic acid. All DNA samples obtained from mature stem tissues were diluted 1:10 with molecular grade water for QPCR analysis.

Real-time QPCR. The primers and probe used for QPCR were designed as described in Strausbaugh et al. (32). The probe was dual-labeled with the 6carboxyfluorescein (6-FAM) fluorescent reporter dye and the 6-carboxyltetramethylrhodamine (TAMRA) fluorescence quencher. The probe was synthesized by PE Applied Biosystems (Foster City, CA) and all the primers used in this study were synthesized by Integrated DNA Technologies, Inc. (Coralville, IA). QPCR assays were performed using the Rotor gene 2000 (Corrbett Research Inc. Sydney, Australia), using a two-step protocol with the following thermocycling parameters: 2 min at $55^{\circ} \mathrm{C}, 10 \mathrm{~min}$ at $94^{\circ} \mathrm{C}$, and $40 \mathrm{cy}-$ cles of $15 \mathrm{~s}$ at $94^{\circ} \mathrm{C}$ and $60 \mathrm{~s}$ at $60^{\circ} \mathrm{C}$. QPCR reactions $(25 \mu \mathrm{l})$ consisted of 12.5 $\mu \mathrm{l}$ of Universal TaqMan Master Mix (PE Applied Biosystems), $2.5 \mu \mathrm{l}$ of $2 \mu \mathrm{M}$ TRI5 TaqMan probe, $2.25 \mu \mathrm{l}$ of $1: 120 \mu \mathrm{M}$ Gzeae87T forward and reverse primers, $2.75 \mu \mathrm{l}$ of molecular grade water, and $5 \mu \mathrm{l}$ of sample DNA. Each real-time run included four 10-fold dilution standards, ranging from 6.6 million copies down to 6,600 copies. The curve produced by plotting the log of the DNA standards concentrations versus the cycle number always had an $R$ value $\geq 0.99$. Reactions were carried out to 40 cycles, which gave a detection limit of approximately 50 copies. Both the DNA standards and no-template control (NTC) samples were run in triplicate for each real-time run. Water controls included in each DNA extraction also were run with each experiment to assess the amount of cross-contamination occurring during the DNA isolation process.

The DNA standard used for absolute quantification during QPCR was a cloned fragment of the tri5 gene from $F$. culmorum isolate 2223 (collected in Loma, MT). The fragment was amplified using primers Fusclone forward (5'-CGGGTC CAGATGTTTGCCAT- $3^{\prime}$ ) and Fusclone reverse $\left(5^{\prime}\right.$-ACTGCTCAATCCAGCAT CCC-3') designed from F. culmorum se- quence GenBank accession no. AY102602. The resulting 680-bp fragment was cloned using Invitrogen's TOPO TA Cloning Kit (Carlsbad, CA) per the manufacturer's instructions and colony selections confirmed with PCR using the primers Gzeae87T forward and Fusclone reverse. The cloned DNA was extracted using Qiagen Mini-prep Kit (Valencia, CA) and sequenced at the Washington State University Core Facility (Pullman) using the Fusclone primer set to confirm its identity.

QPCR specificity and sensitivity among FCR species. The QPCR assay was tested on 10 Fusarium spp. and 12 other plant pathogens representing 13 genera (Table 1). For each species, $10 \mathrm{ng}$ of DNA was tested via QPCR to check for nonspecific reactions and experiments were repeated once in their entirety. To assess the sensitivity of the QPCR assay for $F$. culmorum, $F$. pseudograminearum, and $F$. graminearum, five single-spored isolates were chosen for each species. These 15 isolates were identified to the species level following the guidelines found in Nelson et al. (21), with the identities of representative isolates being verified at the Fusarium Research Institute, University Park, PA. To distinguish between $F$. graminearum and $F$. pseudograminearum, isolates were grown on CLA for 3 weeks at $22^{\circ} \mathrm{C}$, under a combination of cool-white and black-light fluorescent lights, with a 12-h light-and-dark cycle. Plates then were examined for the presence of bluish-black perithecia, which are indicative of $F$. graminearum. The morphological identifications of the 15 FCR isolates were confirmed by PCR using the primer sets $\mathrm{Fc} 01$ (22), Fg16N (22), and Fp1 (1).

These 15 identified FCR isolates then were used to determine sensitivity differences in the QPCR assay among the three FCR species. For this, genomic DNA from $50 \mathrm{mg}$ of freeze-dried mycelia and from 100,000 macroconidia was examined. In addition, $250 \mathrm{ng}$ of DNA from each isolate also was examined via QPCR in case of cell density differences in the mycelia and, consequently, DNA quantity. These experiments were repeated once in their entirety and the data combined after a test for heterogeneity of variances was performed.

Field experiments, FCR ratings, and QPCR. During the summers of 2004 and 2005, wheat cvs. Outlook (19), Choteau (18), and Utopia (World Wide Wheat, LLC.) were grown at the Montana State University Arthur H. Post Research Farm (Bozeman), to be analyzed for FCR severity, Fusarium DNA quantities, and grain yield. Outlook is a hollow-stemmed hard red spring wheat cultivar that is moderately resistant to FCR, Choteau is a solidstemmed hard red spring wheat cultivar that is moderately susceptible to FCR, and Utopia is a durum wheat cultivar (Triticum turgidum) that is highly susceptible to 
FCR. The experiment was planted in a splitplot design with the three cultivars as main plots and the four inoculum rates as subplots. Individual plots were four rows wide, seeded at a rate of 200 seed per 3-m row on $30-\mathrm{cm}$ centers using a small-plot seeder. The experiment was replicated six times. Oat inoculum was sown concurrently with the untreated seed at a rate of $0,4,8$, or $16 \mathrm{~g}$ per 3-m row of inoculum to create varying levels of FCR severity. Oat inoculum was produced as described by Mathre and Johnston (20) using F. pseudograminearum isolate no. 2228 (collected in Loma, MT).

To assess FCR severity, plants were collected at Feekes GS 11.4 from $15 \mathrm{~cm}$ of row at three randomly selected positions in each plot. The positions were limited to the middle rows, with the remaining plants being harvested for yield. Plants were harvested using a binder and threshed using a large-plot Vogel. From the plants collected, 30 tillers were chosen randomly and rated for FCR severity using a crown rot rating (CRR) scale of 1 to 4 . CRRs were based on the presence of brown discolored tissue at the first internode, with a rating of $1=0$ to $25 \%, 2=25$ to $50 \%, 3=50$ to $75 \%$, and $4=$ 75 to $100 \%$ of the internode discolored. The individual CRRs of the 30 stems then were summed to create a disease severity score (DSS) for each plot.

After visually rating the 30 random stems from each plot for FCR severity, 3$\mathrm{mm}$ sections were cut from the stems directly above their crowns to be used for DNA extractions. Because 30 stem sections would overwhelm one 2-ml micro-

Table 1. Quantitative polymerase chain reaction (QPCR) tests conducted with multiple fungal and oomycete genera and species to test the specificity of the assay, which was designed for the tri5 gene to detect members of the Fusarium crown rot complex

\begin{tabular}{|c|c|c|}
\hline Isolate no. ${ }^{y}$ & Fungi tested & QPCR reaction ${ }^{\mathrm{z}}$ \\
\hline 2103 & Fusarium culmorum & + \\
\hline 2223 & F. culmorum & + \\
\hline 2230 & F. culmorum & + \\
\hline 2279 & F. culmorum & + \\
\hline 2286 & F. culmorum & + \\
\hline 423 & F. graminearum & + \\
\hline 468 & F. graminearum & + \\
\hline 2225 & F. graminearum & + \\
\hline 2318 & F. graminearum & + \\
\hline 2319 & F. graminearum & + \\
\hline 2100 & F. pseudograminearum & + \\
\hline 2228 & F. pseudograminearum & + \\
\hline 2234 & F. pseudograminearum & + \\
\hline 2278 & F. pseudograminearum & + \\
\hline 2317 & F. pseudograminearum & + \\
\hline 391 & F. sambucinum & ND \\
\hline 2277 & F. avenaceum & ND \\
\hline 2281 & F. acuminatum & ND \\
\hline 2308 & F. solani & ND \\
\hline 2269 & F. oxysporum & ND \\
\hline 387 & F. monoliforme & ND \\
\hline 2312 & F. equiseti & ND \\
\hline 797 & Verticillium dahliae & ND \\
\hline 781 & Thielaviopsis basicola & ND \\
\hline 796 & Cephlasporium sp. & ND \\
\hline 558 & Gaeumannomyces graminis var. tritici & ND \\
\hline 2121 & Pythium ultimum & ND \\
\hline 566 & Phialophora spp. & ND \\
\hline 1083 & Sclerotinia sclerotium & ND \\
\hline $\mathrm{C} 2$ & Aphanomyces cochlioides & ND \\
\hline Unknown & Penicillium claviforme & ND \\
\hline 2313 & Tapesia yulliande & ND \\
\hline 481 & Rhizoctonia solani & ND \\
\hline 2287 & Bipolaris sporokiniana & ND \\
\hline
\end{tabular}

${ }^{\mathrm{y}}$ Isolate numbers reference cultures from the Soil Disease Lab collection at Montana State University. ${ }^{\mathrm{z}} \mathrm{ND}=$ no detection after 40 PCR cycles. centrifuge tube, the stem sections were divided into three subsamples of $10 \mathrm{sec}-$ tions each for grinding purposes. After grinding, the subsamples were centrifuged and $200 \mu \mathrm{l}$ of supernatant from each of the three subsamples was pooled together to make one sample. DNA then was extracted using the methods described, and samples were analyzed by QPCR. This process was repeated with stem sections taken just above the first and second nodes of the same 30 stems.

Fusarium DNA quantities for CRR groups. To establish Fusarium DNA quantities for each of the visual CRR groups (ratings 1 to 4), plants of Choteau and Outlook were taken from the border rows of field plots at Feekes GS 11.4. The susceptible durum wheat check, Utopia, was not analyzed for this set of experiments due to the fact that not enough CRRs 1 and 2 were available. The leaf tissue was removed and the stems were segregated into the four visual CRR groups. From each of the four CRR groups, five groups of 10 representative stems were chosen randomly. For each group of 10 stems, $3 \mathrm{~mm}$ of tissue was cut from directly above the crown, first node, and second node of each stem and placed in separate tubes for DNA extractions. In total, this gave five replicates for each of the three stem locations per CRR group. DNA samples were extracted using the methods described and then analyzed by QPCR.

Statistics. Statistical regression analysis was performed using Arc Stat XLISPPLUS version 3.04 (http://www.stat.umn. edu/arc/software.html) and analysis of variance (ANOVA) was carried out using MacAnova (http://www.stat.umn.edu/mac anova/). Mean comparisons between threshold cycle $\left(C_{t}\right)$ values were made using a protected Fisher's least significant difference at $P<0.05$. When making comparisons of $\mathrm{C}_{\mathrm{t}}$ values between CRR groups, significant differences were evaluated using pair rank-sum tests.

\section{RESULTS}

QPCR specificity and performance. The QPCR assay detected all 15 of the FCR isolates it was designed for but failed to detect any of the other fungi tested (Table 1). However, the sensitivity of the QPCR assay was significantly different $(P<0.05)$ among the three FCR species (Table 2). For

Table 2. Relative sensitivity of the quantitative polymerase chain reaction assay for detecting Fusarium graminearum, F. pseudograminearum, and F. culmorum using DNA from $50 \mathrm{mg}$ of freeze-dried mycelia, 100,000 macroconidia, and a standardized amount $(250 \mathrm{ng})^{\mathrm{z}}$

\begin{tabular}{|c|c|c|c|c|c|c|}
\hline \multirow[b]{2}{*}{ Species } & \multicolumn{2}{|c|}{50 of mg mycelia } & \multicolumn{2}{|c|}{ 100,000 Macroconidia } & \multicolumn{2}{|c|}{$250 \mathrm{ng}$ of DNA } \\
\hline & $\mathbf{C}_{\mathrm{t}}$ & Copy no. & $\mathbf{C}_{\mathrm{t}}$ & Copy no. & $\mathrm{C}_{\mathrm{t}}$ & Copy no. \\
\hline F. graminearum & $16.57 \mathrm{a}$ & $112,989,406$ & $31.24 \mathrm{a}$ & 9,691 & $16.14 \mathrm{a}$ & $84,444,820$ \\
\hline F. pseudograminearum & $18.22 \mathrm{~b}$ & $29,979,512$ & $31.63 \mathrm{a}$ & 6,508 & $17.18 \mathrm{~b}$ & $42,980,166$ \\
\hline F. culmorum & $20.75 \mathrm{c}$ & $8,525,476$ & $34.66 \mathrm{~b}$ & 425 & $19.11 \mathrm{c}$ & $12,811,916$ \\
\hline LSD & 0.93 & $\ldots$ & 1.77 & $\ldots$ & 0.70 & $\ldots$ \\
\hline
\end{tabular}

${ }^{\mathrm{z}}$ Mean threshold cycle $\left(\mathrm{C}_{\mathrm{t}}\right)$ and copy values represent five isolates per species combined over two experiments. $\mathrm{C}_{\mathrm{t}}$ values followed by different letters are significantly different from each other at $P<0.05$ using Fisher's protected least significant difference (LSD). 
mycelia, macroconidia, and standardized DNA samples, $F$. graminearum isolates always had the highest sensitivity (i.e., had the lowest $C_{t}$ value). The sensitivity of the QPCR assay diminished as one went from $F$. graminearum to $F$. pseudograminearum and from $F$. pseudograminearum to $F$. culmorum. For instance, the sensitivity of the assay for $F$. pseudograminearum was about half $(0.51)$ that of $F$. graminearum for the same amount of standardized DNA. For F. culmorum, the assays sensitivity was even lower, at about one-seventh $(0.15)$ that of $F$. graminearum. The pattern in sensitivity differences was not significantly different if one analyzed DNA yields from macroconidia or mycelia, instead of a standardized concentration of DNA from the three species $(P<0.05)$.

CRRs and Fusarium DNA quantities. For the spring wheat cv. Outlook in 2004, Fusarium DNA quantities in crown tissues of CRR 2 samples were significantly less than those in CRR 3 samples, and Fusarium DNA quantities in CRR 3 samples were significantly less than those in CRR 4 samples $(P<0.01)$. Similar results were obtained for both node 1 and node 2 tissues. However, significant differences between CRR 1 samples and CRR 2 samples existed only for crown tissues $(P<$ 0.05 ), not node 1 or node 2 tissues (Fig. 1A). In 2005, similar results were obtained for Outlook except that CRR 1 samples and CRR 2 samples were significantly different from each other only for node 2 tissue $(P<0.01)$, not crown or node 1 tissues. In addition, CRR 2 samples were significantly different only from CRR 3 samples for crown and node 1 tissues, not node 2 tissues (Fig. 1B).

For the spring wheat cv. Choteau in 2004, Fusarium DNA quantities in crown tissues were significantly lower in CRR 1 samples than those in CRR 2 samples, and Fusarium DNA quantities in CRR 3 samples were significantly less than those in CRR 4 samples $(P<0.05)$. This also was true for both node 1 and node 2 tissues. CRR 2 samples had significantly less Fusarium DNA than CRR 3 samples for node 1 tissues $(P<0.05)$, but not for the crown or node 2 tissues (Fig. 1C). In 2005, similar results were obtained for Choteau, except that CRR 1 and CRR 2 samples were not significantly different from each other at crown and node 1 tissues, just node 2 tissue (Fig. 1D). Also, CRR 2 samples were not significantly different from CRR 3 samples for any of the tissues.

In 2005, Fusarium DNA quantities measured for the four CRR groups for both Choteau and Outlook were significantly lower $(P<0.05)$, in most cases, than those calculated for 2004 samples (Fig. 1). On average, Fusarium DNA quantities for similar CRR groups in 2005 Outlook samples were $30 \%$ of those detected in 2004 samples. For Choteau 2005 samples, Fusarium DNA quantities for similar CRR groups were, on average, $46 \%$ of those detected in 2004.

Field plots and regression analysis. In 2004, Fusarium DNA quantities obtained from above the crown, first node, and second node significantly positively correlated $(P \leq 0.001)$ with DSS for cv. Choteau (Fig. 2; Table 3). Fusarium DNA quantities obtained from Choteau crown samples were significantly $(P<0.05)$ negatively correlated with grain yields, whereas no correlation was found for node 1 or node 2 samples (Fig. 3; Table 3). For Choteau, there was no correlation between DSS and grain yield (Table 3 ).

For Outlook in 2004, crown, node 1, and node 2 samples had Fusarium DNA quantities that positively correlated $(P<0.01)$ with DSS (Fig. 2; Table 3). Outlook Fusarium DNA quantities also were significantly negatively associated $(P<0.05)$ with grain yields for all three stem locations (Fig. 3; Table 3). The relationship between Fusarium DNA quantities and yield for Outlook (i.e., the slope of the line) was not significantly different from that obtained for Choteau $(P=0.10)$. Also, the relationship between Fusarium DNA quantities and DSS was similar for Outlook and Choteau for crown, node 1 , and node 2 tissues $(P=0.27,0.30$, and 0.94 , respectively). For Outlook, DSS negatively
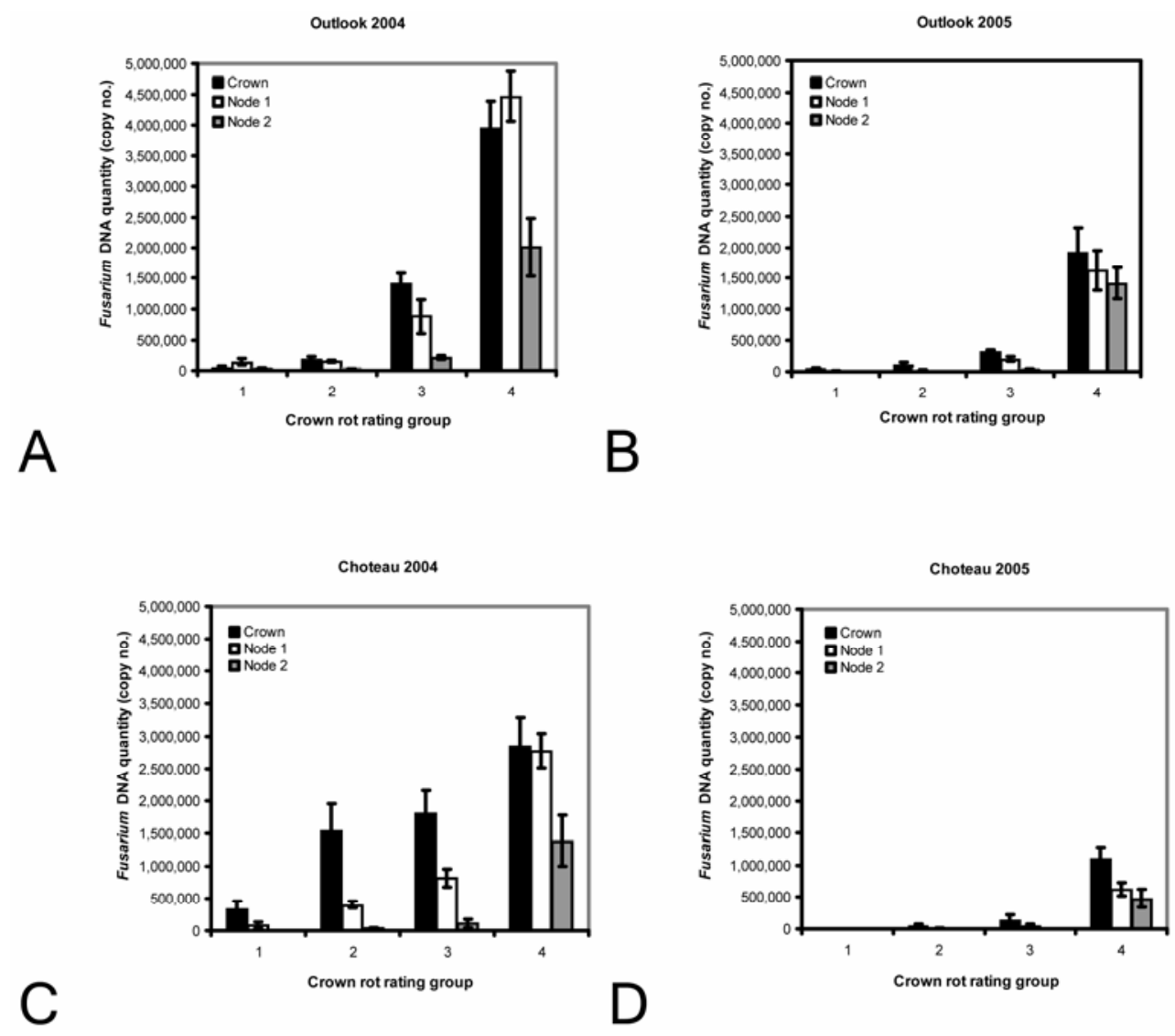

Fig. 1. Fusarium DNA quantities (copy number) at the crown, first node, and second node for Fusarium crown rot rating groups 1 to 4 . Two spring wheat cultivars, A and B, Outlook and C and D, Choteau, were analyzed in 2004 and 2005. Error bars represent standard errors. 
correlated $(P<0.001)$ with grain yields (Table 3).

For Utopia in 2004, all three stem locations had Fusarium DNA quantities that positively correlated $(P<0.05)$ with DSS (Fig. 2; Table 3). The relationship between Fusarium DNA quantities and DSS for crown and node 1 tissues was significantly different from that obtained for Choteau and Outlook $(P<0.01)$. The relationship between Fusarium DNA quantities and DSS at node 2 for Utopia was not significantly different from that for Choteau and Outlook $(P=0.10)$. No significant associations were observed when Utopia Fusarium DNA quantities were regressed against grain yields. Associations between Utopia DSS and grain yields also were not detected.

In 2005, significant positive correlations between DSS and Fusarium DNA quantities at the crown, node 1 , and node $2(P<$ 0.01 ) tissues existed for the susceptible cv. Utopia (Table 3). However, the relationship between Fusarium DNA quantities and DSS for crown, node 1 , and node 2 tissues for Utopia in 2005 was significantly different from those obtained for Utopia in $2004(P<0.05)$. No significant correlations between DSS and Fusarium DNA quantities were observed for Choteau or Outlook at any stem location $(P<0.05)$. Choteau DSS was the only variable that significantly correlated with grain yield losses in $2005(P=0.017)$. Average DSS for Choteau $(P=0.022)$, Outlook $(P<$ $0.001)$, and Utopia $(P<0.001)$ were significantly lower in 2005 than 2004 by 38, 80 , and 70 units, respectively (Fig. 4A). The average Fusarium copy number for Choteau, Outlook, and Utopia also was significantly lower $(P<0.001)$ by approximately 1.1 million, 1 million, and 2.8 million copies, respectively, in 2005 (Fig. 4B). Grain yields in 2005 were significantly higher $(P<0.001)$ for Choteau $(+10.6 \%)$, Outlook $(+10.9 \%)$, and Utopia $(+20.0 \%)$ than those in 2004.

\section{DISCUSSION}

Our studies represent the first field studies correlating Fusarium DNA quantities determined by QPCR with traditional FCR disease assessments and yield reductions. Using the same QPCR assay, Strausbaugh et al. (32) were unable to detect relationships between traditional Fusarium root-rot severities and Fusarium DNA quantities in field samples. This likely was due to a combination of reasons, one of the major reasons being that they were sampling root tissue. By sampling roots, one must assess larger amounts of plant material to accurately determine pathogen populations and disease levels. Also, by sampling roots, soil is introduced into the DNA extraction process which, if improperly handled, is known to inhibit downstream applications. Another potential reason may be that the organism they were targeting, F. cul- morum, has a lower detection level with this QPCR assay, as we have demonstrated. In other studies utilizing quantitative competitive PCR techniques, re- searchers also had difficulties in finding significant associations between crown rot severity and pathogen DNA quantities $(5,22,34)$. We believe we succeeded be-

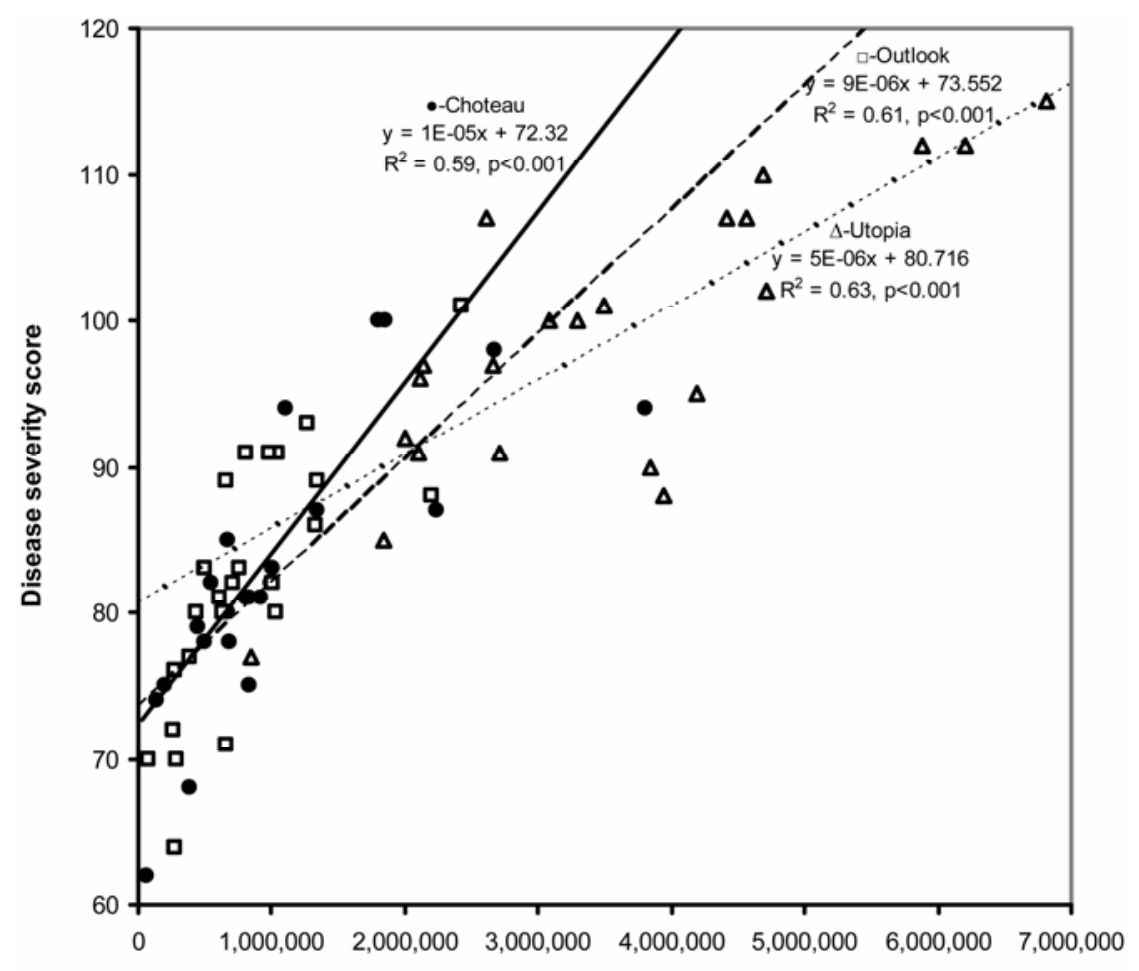

Fusarium DNA quantity (copy no.) - node 1

Fig. 2. Relationships between Fusarium DNA quantities (copy number) at node 1 and Fusarium crown rot disease severity scores for two spring wheat cultivars, Choteau and Outlook, and a durum wheat cultivar, Utopia, in 2004.

Table 3. Results of regression analyses between Fusarium DNA quantities (at crown, node 1, and node 2), disease severity scores (DSSs), and grain yields for spring wheat cvs. Outlook and Choteau and durum wheat cv. Utopia for years 2004 and 2005

\begin{tabular}{|c|c|c|c|c|}
\hline \multirow[b]{2}{*}{ Cultivar, regression ${ }^{y}$} & \multicolumn{2}{|c|}{2004} & \multicolumn{2}{|c|}{2005} \\
\hline & $\boldsymbol{R}$ & $\boldsymbol{P}$ & $\boldsymbol{R}$ & $P$ \\
\hline \multicolumn{5}{|l|}{ Outlook } \\
\hline Yield:Crown & -0.77 & $<0.001$ & 0.07 & 0.510 \\
\hline Yield:Node 1 & -0.78 & $<0.001$ & 0.20 & 0.504 \\
\hline Yield:Node 2 & -0.42 & 0.039 & 0.02 & 0.932 \\
\hline Yield:DSS & -0.64 & $<0.001$ & -0.15 & 0.487 \\
\hline DSS:Crown & 0.83 & $<0.001$ & 0.30 & 0.183 \\
\hline DSS:Node 1 & 0.84 & $<0.001$ & 0.01 & 0.958 \\
\hline DSS:Node 2 & 0.63 & $<0.001$ & 0.24 & 0.264 \\
\hline \multicolumn{5}{|l|}{ Choteau } \\
\hline Yield:Crown & -0.41 & 0.045 & 0.02 & 0.935 \\
\hline Yield:Node 1 & -0.38 & 0.066 & -0.10 & 0.652 \\
\hline Yield:Node 2 & -0.17 & 0.433 & 0.14 & 0.528 \\
\hline Yield:DSS & -0.18 & 0.536 & -0.48 & 0.017 \\
\hline DSS:Crown & 0.64 & $<0.001$ & -0.07 & 0.759 \\
\hline DSS:Node 1 & 0.80 & $<0.001$ & 0.10 & 0.628 \\
\hline DSS:Node 2 & 0.85 & $<0.001$ & -0.20 & 0.339 \\
\hline \multicolumn{5}{|l|}{ Utopia } \\
\hline Yield:Crown & -0.05 & 0.822 & -0.14 & 0.511 \\
\hline Yield:Node 1 & $-0.05^{\mathrm{z}}$ & 0.829 & -0.36 & 0.082 \\
\hline Yield:Node 2 & 0.05 & 0.801 & -0.21 & 0.330 \\
\hline Yield:DSS & 0.18 & 0.382 & -0.22 & 0.472 \\
\hline DSS:Crown & 0.42 & 0.041 & 0.63 & 0.003 \\
\hline DSS:Node 1 & $0.63^{z}$ & 0.001 & 0.86 & $<0.001$ \\
\hline DSS:Node 2 & 0.70 & $<0.001$ & 0.79 & $<0.001$ \\
\hline
\end{tabular}

${ }^{\text {y }}$ Crown, Node 1 , Node $2=$ Fusarium DNA copy numbers at said stem location and DSS $=$ disease severity scores for experimental plots.

$\mathrm{z}$ Two outliers were removed from the regression analysis. 
cause we focused on specific areas where Fusarium populations and FCR symptoms were most relevant to yield reductions. We also used $F$. pseudograminearum as an inoculum source, which allowed us greater sensitivity with this QPCR assay. In some instances, the invariable levels of disease preclude the detection of relationships. This occurred in our work and also may have affected these other studies.

Paulitz et al. (24) and Smiley et al. (29) indicated that disease measures taken at the fourth internode correlated best with yield reductions in the Pacific Northwest. In Montana, progression of symptoms to the fourth internode is very rare; therefore, we did not sample that high on the stem. Nevertheless, we did not find that Fusarium DNA quantities obtained from one stem location were superior to another at predicting DSS or yield losses based on $R$ values from regression analysis. In some instances, Fusarium DNA quantities in crown tissues related best to DSS and yield loss (when applicable) whereas, in other cases, Fusarium DNA quantities from node 1 or node 2 tissue showed the strongest relationships. Over the 2 years, we found that DSS and Fusarium DNA quantities were comparable in predicting yield reductions through regression analysis. When both Fusarium DNA quantities and DSS were correlated with yield reductions for Outlook in 2004, Fusarium DNA quantities from the crown correlated marginally better than DSS. However, in 2005, the only data that significantly correlated with a yield reduction was DSS for Choteau plots.
When comparing disease evaluations across years, the relationship between Fusarium DNA quantities and traditional FCR disease measures was unstable. This is illustrated most clearly by differences in Fusarium DNA quantities for CRR groups 1 to 4 in 2004 versus those in 2005. For both Choteau and Outlook, CRR groups 2, 3 , and 4 had significantly less Fusarium DNA quantities in crown tissues in 2005 than those in 2004. These differences also were evident in field plots. For all three cultivars in 2005, Fusarium DNA quantities were roughly one-seventh the amount predicted based on 2004's data. We tested whether these differences might be a result of changes in the QPCR process by running several samples from both years in tandem and obtained similar results. Although we cannot be certain, we suspect that the relatively low disease intensity in 2005 led to the unintentional inflation of our visual disease ratings for that year. Other confounding factors, such as environmental conditions or the presence of other wheat pathogens, also could account for some of the instability in the relationship between DSS and Fusarium DNA quantities. These factors may enhance symptom expression or inhibit Fusarium population growth in infested tissues.

The four visual CRR groups could not always be statistically distinguished from one another based on Fusarium DNA quantities. Because nonparametric analyses were used, we believe the inability to consistently differentiate the four CRR groups was not the result of large variances

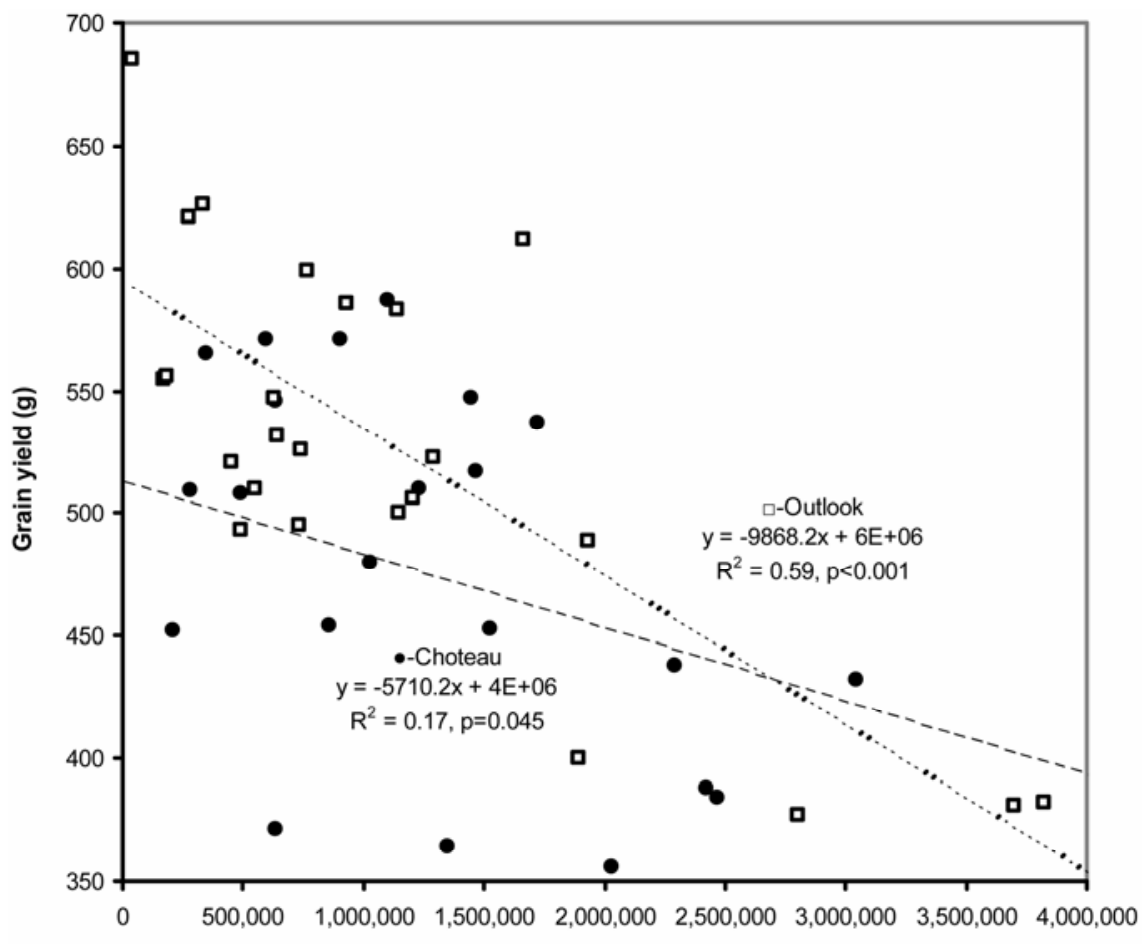

Fusarium DNA quantity (copy No.) - crown

Fig. 3. Relationships between Fusarium DNA quantities (copy number) at the crown and grain yields for two spring wheat cultivars, Choteau and Outlook, in 2004. but rather the difficulty in visually distinguishing between the disease categories. Most of the problems occurred when trying to separate CRRs 2 and 3. The results show that Fusarium DNA quantities tended to increase exponentially when moving up the visual disease scale. In other words, our visual disease assessments only discriminate between large differences in pathogen populations. These results support consolidating the four CRR categories into three categories representing low, medium, and high disease levels. Obviously, relationships between visual disease assessments and pathogen populations are not perfect and the performance of a three-category system should be compared with the four-category system in terms of predicting yield losses.

Due to genetic similarities, the QPCR assay developed by Strausbaugh et al. (32) detects three of the Fusarium spp. known to cause FCR in Montana: F. graminearum, $F$. pseudograminearum, and $F$. culmorum. Our analysis of these species demonstrated that the sensitivity of the QPCR assay is not equal among them and diminishes as one goes from $F$. graminearum to $F$. pseudograminearum to $F$. culmorum. This is true whether one uses standardized amounts of DNA, mycelia, or macroconidia. The difference in the QPCR
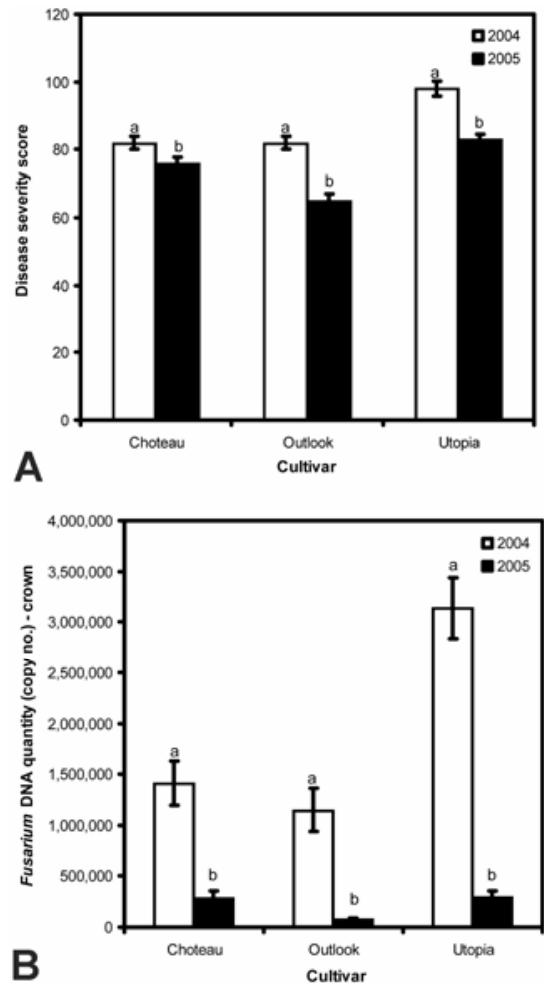

Fig. 4. A, Average Fusarium crown rot disease severity scores and B, Fusarium DNA quantities (copy number) at the crown for two spring wheat cultivars, Choteau and Outlook, and a durum wheat cultivar, Utopia, in 2004 and 2005. Columns with different letters are significantly different at $P<0.001$, except Choteau disease severity scores, where $P=0.022$. Error bars represent standard errors. 
assays sensitivity does not appear to be completely related to sequence homology. Basic local alignment search tool (BLAST) searches of the NCBI database using the 63-bp amplicon revealed a greater sequence homology in F. culmorum entries than $F$. pseudograminearum entries. This may be due to the location and type of base mismatches involved rather than in the total number of mismatches. In addition to the three FCR species included in this study, a BLAST search revealed other Fusarium spp. that might be detected with this assay, such as $F$. lunulosporum Gerlach, F. cerealis, F. sporotrichioides Sherb., and $F$. poae (Peck) Wollenw. These other Fusarium spp. are not commonly isolated in Montana, but this should be taken into consideration when using this assay.

In some instances, there was no correlation between Fusarium DNA quantities and DSS or Fusarium DNA quantities and yield reductions. In the case of Utopia in 2004, the high susceptibility of the cultivar led to uniform high disease severity and, in turn, a uniform yield loss. For the cases involving Choteau and Outlook in 2005, the lack of correlation was likely the result of unfavorable FCR conditions and low disease intensity. The climatic conditions during the 2005 growing season were considerably wetter and cooler than those in 2004. The wetter, cooler weather is not conducive for the development of FCR $(6,8,10,12,23,28,29)$ and, therefore, there were lower disease levels, lower Fusarium DNA quantities, and correspondingly little to no impact of disease on yield.

This research has demonstrated that the estimation of Fusarium DNA quantity via QPCR can be an effective method for assessing FCR in mature wheat stems under certain conditions. When environmental stress is high and targeted pathogens are present in moderate numbers, QPCR performed as well as, if not better than, traditional disease assessment methods for evaluating field plots. However, when pathogen populations were low and plants were not stressed, QPCR was not an improvement over traditional methods. QPCR has helped revolutionize the field of diagnostic plant pathology by allowing investigators to accurately quantify a specific pathogen within a myriad of host tissues and environmental samples. Due to the increasing adoption of NTC practices, there is potential for an increase in residue-borne Fusarium populations $(3,4,33)$. Monitoring Fusarium populations in decaying stem tissue using traditional plating methods is difficult and imprecise because of the plethora of microorganisms present. In addition to assessing plants for FCR severity, the QPCR assay described here could be used in the future to monitor Fusarium populations living on wheat residues and help understand the dynamics of their survival and their importance in disease development.

\section{ACKNOWLEDGMENTS}

This project was supported by the National Research Initiative of the United States Department of Agriculture Cooperative State Research, Education and Extension Service, grant number 2005-3531916193 and by the Montana Agricultural Experiment Station. We thank C. Strausbaugh for providing us with the QPCR primer and probe sequences and all of our anonymous reviewers for their thoughtful comments.

\section{LITERATURE CITED}

1. Aoki, T., and O'Donnell, K. 1999. Morphological and molecular characterization of Fusarium pseudograminearum sp. nov., formerly recognized as the group I population of F. graminearum. Mycologia 91:597-609.

2. Backhouse, D., Abubakar, A. A., Burgess, L. W., Dennis, J. I., Holloway, G. J., Wildermuth, G. B., Wallwork, J., and Henry, F. J. 2004. Survey of Fusarium species associated with crown rot of wheat and barley in eastern Australia. Australas. Plant Pathol. 33:255-261.

3. Bailey, K. L. 1996. Diseases under conservation tillage systems. Can. J. Plant Sci. 76:635639.

4. Bailey, K. L., Mortensen, K., Lafond, G. P., Watson, P. R., and Derksen, D. A. 2001. Effect of tillage and crop rotation on root and foliar diseases of wheat and pea in Saskatchewan from 1991-1998: univariate and multivariate analyses. Can. J. Plant Sci. 81:789-803.

5. Bateman, G. L., Edwards, S. G., Marshall, J., Morgan, L. W., Nicholson, P., Nuttall, M., Parry, D. W., Scrancher, M., and Turner, A. S. 2000. Effects of cultivar and fungicides on stem-base pathogens, determined by quantitative PCR, and on diseases and yield of wheat. Ann. Appl. Biol. 137:213-221.

6. Beddis, A. L., and Burgess L. W. 1992. The influence of plant water stress on infection and colonization of wheat seedlings by Fusarium graminearum group 1. Phytopathology 82:7883.

7. Bluhm, B. H., Cousins, M. A., and Woloshuk, C. P. 2004. Multiplex real-time PCR detection of fumonisin-producing and trichotheceneproducing groups of Fusarium species. J. Food Prot. 76:536-543.

8. Burgess, L. W., Backhouse, D., Summerell, B. A., and Swan, L. J. 2001. Crown rot of wheat. Pages 271-294 in: Fusarium: Paul E. Nelson Memorial Symposium. B. A. Summerell, J. F. Leslie, D. Backhouse, W. L. Bryden, and L. W. Burgess, eds. American Phytopathological Society, St. Paul, MN.

9. Cook, R. J. 1968. Fusarium root and foot rot of cereals in the Pacific Northwest. Phytopathology 58:127-131.

10. Cook, R. J. 1980. Fusarium foot rot of wheat and its control in the Pacific Northwest. Plant Dis. 64:1061-1066.

11. Cook, R. J. 1981. Fusarium diseases of wheat and other small grains in North America. Pages 39-52 in: Fusarium: Diseases, Biology and Taxonomy. P. E. Nelson, T. A. Toussoun, and R. J. Cook, eds. The Pennsylvania State University Press, University Park

12. Cook, R. J., and Papendick, R. I. 1970. Soil water potential as a factor in the ecology of Fusarium roseum f. sp. cerealis 'culmorum'. Plant Soil 32:131-145.

13. Gao, X., Jackson, T. A., Lambert, K. N., Li, S., Hartman, G. L., and Niblack, T. L. 2004. Detection and quantification of Fusarium solani f. sp. glycines in soybean roots with real-time quantitative polymerase chain reaction. Plant Dis. 88:1372-1380.

14. Heid, C. A., Stevens, J., Livak, K. J., and Williams, P. M. 1996. Real-time quantitative
PCR. Genome Methods 6:986-994.

15. Hill, J. P., Fernandez, J. A., and McShane, M. S. 1983. Fungi associated with common root rot of winter wheat in Colorado and Wyoming. Plant Dis. 67:795-797.

16. Kane, R. T., Smiley, R. W., and Sorrells, M. E. 1987. Relative pathogenicity of selected Fusarium species and Microdochium bolleyi to winter wheat in New York. Plant Dis. 71:177-181.

17. Klein, T. A., Burgess, L. W., and Ellison, F. W. 1991. The incidence and spatial patterns of wheat plants infected by Fusarium graminearum group 1 and the effect of crown rot on yield. Aust. J. Agric. Res. 42:399-407.

18. Lanning, S. P., Carlson, G. R., Nash, D. Wichman, D. M., Kephart, K., Stougaard, R. N., Kushnak, G. D., Eckhoff, J. L., Grey, W. E., and Talbert, L.E. Registration of 'Choteau' wheat. 2004. Crop Sci. 44:2263-2264.

19. Lanning, S. P., Habernicht, D., Wichman, D. M., Kephart, K. D., Stougaard, R. N., Kushnak, G. D., Eckhoff, J. L., Carlson, G. R., Grey, W. E., and Talbert, L. E. Registration of 'Outlook' wheat. 2003. Crop Sci. 43:23022303.

20. Mathre, D. E., and Johnston, R. H. 1975. Cephalosporium stripe of winter wheat: procedures for determining host response. Crop Sci. 15:591-594

21. Nelson, P. E., Toussoun, T. A., and Marasas, W. F. O. 1983. Fusarium Species: An Illustrative Manual for Identification. The Pennsylvania State University Press, University Park.

22. Nicholson, P., Simpson, D. R., Weston, G. Rezanoor, H. N., Lees, A. K., Parry, D. W., and Joyce, D. 1998. Detection and quantification of Fusarium culmorum and Fusarium graminearum in cereals using PCR assays. Physiol. Mol. Plant Pathol. 53:17-37.

23. Papendick R. I., and Cook R. J. 1974. Plant water stress and the development of Fusarium foot rot in wheat subjected to different cultural practices. Phytopathology 64:358-363.

24. Paulitz, T. C., Smiley, R. W., and Cook, R. J. 2002. Insights into the prevalence and management of soil borne cereal pathogens under direct seeding in the Pacific Northwest, U.S.A. Can. J. Plant Pathol. 24:416-428.

25. Pettitt, T., Xiangming, X., and Parry, D. 2003. Association of Fusarium species in the wheat stem rot complex. Eur. J. Plant Pathol. 109:769-774.

26. Reischer, G. H., Lemmens, M., Farnleitner, A. Adler, A., and Mach, R. L. 2004. Quantification of Fusarium graminearum in infected wheat by species specific real-time PCR applying a TaqMan probe. J. Microbiol. Methods 59:141-146.

27. Schnerr H., Niessen, L., and Vogel, R. F. 2001. Real-time detection of the tri5 gene in Fusarium species by LightCycler-PCR using SYBR Green I for continuous fluorescence monitoring. Int. J. Food Microbiol. 71:53-61.

28. Smiley, R. W., Collins, H. P., and Rasmussen, P. E. 1996. Diseases of wheat in long-term agronomic experiments at Pendleton, Oregon. Plant Dis. 80:813-820.

29. Smiley, R. W., Gourlie, J. A., Easley, S. A., Patterson, L. M., and Whittaker, R. G. 2005. Crop damage estimates for crown rot of wheat and barley in the Pacific Northwest. Plant Dis. 89:595-604.

30. Smiley, R. W., and Patterson, L. M. 1996. Pathogenic fungi associated with Fusarium foot rot of winter wheat in the semiarid Pacific Northwest. Plant Dis. 80:944-949.

31. Strausbaugh, C. A., Bradley, C. A., Koehn, A. C., and Forster, R. L. 2004. Survey of root diseases of wheat and barley in Southwestern Idaho. Can. J. Plant Pathol. 26:167-176.

32. Strausbaugh, C. A., Overturf, K., and Koehn, A. C. 2005. Pathogenicity and real-time PCR detection of Fusarium spp. in wheat and barley 
roots. Can. J. Plant Pathol. 27:430-438.

33. Summerall, B. A., Burgess, L. W., and Klein, T. A. 1989. The impact of stubble management on incidence of crown rot of wheat. Aust. J. Exp. Agric. 29:91-98.

34. Turner, A. S., Nicholson, P., Edwards, S. G., Bateman, G. L., Morgan, L. W., Todd, A. D., Parry, D. W., Marshall J., and Nuttall, M. 2002. Relationship between brown foot rot and DNA of Microdochium nivale, determined by quantitative PCR, in stem bases of winter wheat. Plant Pathol. 51:464-471.

35. Waalwijk, C., Hiede, R., Vries, I., Lee, T., Schoen, C., Corainville, C., Häuser-Hahn, I., Kastelein, P., Köhl, J., Lonnet, P., Demarquet, T., and Kema, G. H. J. 2004. Quantitative detection of Fusarium species in wheat using TaqMan. Eur. J. Plant Pathol. 110:481-494.

36. Wallwork, H., Butt, M., Cheong, P. E., and Williams, K. J. 2004. Resistance to crown rot in wheat identified through and improved method for screening adult plants. Aust. J. Plant Pathol.

37. Wiese, M. V. 1987. Compendium of Wheat Diseases, 2nd ed. American Phytopathological Society, St. Paul, MN

38. Windels, C. E. 2000. Economic and social impacts of Fusarium head blight: changing farms and rural communities in the Northern Great Plains. Phytopathology 90:17-21. 